\title{
THE CONCEPT OF MORAL PERSON
}

CARLOS SANTIAGO NINO

Univeraidad de Buenos Aires

The purpose of this work is to make some contribution towards the elucidation of the concept of moral person, that is the bearer of basic moral rights. I wish to explore the connection between this concept and the class of human beings. I shall defend an outlook which has relevant implications, that I shall mention only in passing at the end of the article, in relation to such trascendent topics as the morality of abortion and euthanasia, the rights of animals and collective entities, and the moral status of future generations.

1. I think that most people accept that there is an intimate relationship between the property of being a human individual and the property of being entitled to the basic rights which are inherent in moral personality.

This conviction is so widespread that the fundamental moral rights are universally labelled "human rights" and they are often characterized as those rights which are enjoyed by all men and by nobody but men.

If this implies that the fact of being a man is a necessary and sufficient condition for enjoying these rights, that statement presents some difficulties. First, there are some conditions of negative character (like not having committed a crime) which are required to enjoy various general rights. Secondly, there are other conditions which are required to enjoy some specific rights, like the fact of being ill with regard to the right of proper medical attention. However, the first difficulty can be 
overcome if we distinguish, following Joseph $\operatorname{Raz}^{1}$ a set of conditions (call them "perspicuous") which are relevant to the grounds of the normative solutions, and we state that the only perspicuous condition for enjoying fundamental moral rights is the fact of being human. As for the second difficulty, we may overcome it by way of alleging that a right like that which refers to medical attention is only instrumental to the basic right to health which is, indeed, enjoyed by all men.

The statement that the only relevant condition for bearing fundamental moral rights is the fact of being human seems quite plausible, since it satisfies a deeplyrooted egalitarian aspiration: this is so because the property of being human seems to be of the "all-ornothing" kind, unlike other properties-such as those of being tall, rich or clever-which are, as it is obvious, gradual.

An important consequence follows from this: in the same way that the formal feature of the supervenience of moral principles implies that they cannot establish different normative solutions between cases unless they differ in relevant factual properties, moral principles cannot establish different degrees for a normative solution (e.g. rights to a lesser or greater amount of some goods) if they do not differ in the degree in which the relevant property is given. Hence, if the only relevant property for enjoying some rights is the fact of being human, and if this property does not admit degrees, this means that there cannot be differences of degree in the extent to which the rights in question are held; that is, all men must have them in the same degree.

This analysis has the advantage of allowing us to assign an adequate sense to the slogan "all men are equal".

1 See "Principles of Equality", Mind, vol. LXXXVII, Num. 347, July 1978 , p. 322. 
If it is interpreted ${ }^{2}$ as a descriptive proposition, it is false, since, as it is obvious, men differ in many traits. If, on the other hand, it is interpreted as a normative proposition, the slogan is not very plausible unless submitted to several qualifications, since even the most convinced egalitarians admit that all men should not be treated equally (we should not treat a disabled person in the same way as a healthy one). But the slogan has sense and seems plainly acceptable if we interpret it as what, in some sense, may be deemed an analytic proposition, that is a proposition that asserts that the predicate "man" has an "all-or-nothing" character, and that, therefore, all men are equally men. This is in no way trivial, since the same is not true of other predicates: not all wise people are equally wise and not all fat people are equally fat.

But all this construction hangs on a presupposition which we must put into question: is it true that the predicate "man" is not of a gradual kind?

To begin with, it does not seem plausible to suppose that the predicate "man" refers to a primitive or unanalyzable property, as it is perhaps that referred to by the predicate "red". Therefore, whether the meaning of "man" has an "all-or-nothing" or a gradual nature will depend on the more primitive properties in terms of which it is characterized.

When we want to analyze the predicate "man" we face the following alternative: either we characterize it in relation to some biological properties or we rely on traits such as those of rationality, intelligence, capacity to decide or to choose values, etc.

If we adopt the first term of the alternative, the non-gradual character of the predicate "man" seems to

2 See an analyais of this point in Benn and Peter, Social Principles and the Democratic States, London, 11 th edition. 
be guaranteed: the membership to the "homo-sapiens" species does not admit degrees. I suppose that it is not easy to agree about the features which determine that membership, but if, for instance, we took as a distinctive feature the number of chromosomes in the cell nucleus, we would have a criterion which, except for very exceptional cases, does not present grey zones.

For a series of theoretical and practical purposes we need to use a concept of man which is defined in biological terms and which presents, thus, this "all-ornothing" character. But we must ask ourselves whether such a concept may be also relevant for the purposes of adscribing such important normative consequences as the entitlement to certain basic moral rights. The answer can be hardly positive, since it is difficult to see how a purely biological fact-as may be that of having cells with 46 chromosomes in their nucleus-should be morally relevant. The opposite conclusion seems to be similar to racialist stands which make the recognition of certain rights dependant on the fact of belonging to one of the human races. On the basis of this analogy, many defenders of the rights of animals have maintained that to limit the recognition of certain rigths to a class which is defined in biological terms implies to incur in a "specism" which is so groundless and repugnant as racialism.

The other term of the alternative-i.e. to analyze the predicate "man" in relation to properties such as rationality or capacity to decide- seems to be free from the above difficulty, since these traits are at first sight highly relevant for ascribing fundamental rights, like, e.g., those of freedom of expression or religion. However this option has another highly undesirable consequence: the properties in question are not of an "all-or-nothing" but of a gradual kind, which means that, if the predi- 
cate "man" were defined in relation to them, it would acquire also a gradual character. The immediate implications, according to what we have seen, would be that the slogan "all men are equal" is false, even in its "analytic" interpretation, and that, by application of the afore-mentioned extended principle of supervenience, men would be entitled to rights of different degrees according to their degree of rationality, intelligence, capacity of choosing values, etc. This elitist outlook is even more shocking than the specist one we consider before.

In the face of this unpalatable dilemma I think that we must identify and reject a presupposition that leads us to it: the presupposition that the concept of moral person must denote a class of individuals (like the class of men) which distinguished themselves by factual properties that are mentioned in fundamental moral principles as conditions for being entitled to certain rights.

I think that we must take into account that, as Bruce Ackerman says, ${ }^{3}$ moral citizenship is not a question of biological theory (or, for that matter, of any other sort of factual theory) but of political theory, that is of moral theory in a broad sense. That means that we need to produce a radical change of philosophical strategy in the characterization of moral personality: we must have first the moral principles from which basic rights derive, and then we can define the class of moral persons as the class of all those individuals (or entities) who possess the properties which are factually necessary for enjoying or exercizing those rights. This means that the fundamental principles from which basic rights derive are cathegorical, in the sense that they do not condition the entitlement to those rights to the possession of

see Social Jurtice and the Liberal Slate, New Haven, 1980, p. 78. 
some trait or other. These principles are erga omnes, i.e. they apply to everybody or everything. It is just a question of fact that only some individuals or entities can enjoy or exercize to certain degree the rights generated by those principles. This presupposes, of course, a distinction between being entitled to a certain right and being factually able to exercize it: $m y$ right to free speech implies the right of speaking in Chinese, and this is, thus, a right which $I$ have but cannot exercize. The idea is that moral personality is a concept related not to the fact of having or being entitled to fundamental moral rights but to the fact of possessing the conditions for exercizing or enjoying them.

If this is so, the relation between the class of moral persons and the class of men is a contingent one and there is no a priori guarantee that all moral persons are men, that all men are moral persons and that all men have the same degree of moral personality. But these conclusions do not seem now objectionable (as they were when they referred to the entitlement to certain rights) since they are based not on some arbitrary limitation in our moral principles, but on hard facts which determine the possibility or impossibility of exercizing the rights which derive from them.

This heterodox vision of moral personality has extremely relevant ethical implications. In order to examine them-even in the quick fashion in which I shall do it in the last section-it is necessary to state briefly the principles from which, in my opinion, fundamental rights derive. This is the object of the next section.

2. I have defended elsewhere ${ }^{4}$ three basic principles from which basic moral rights derive (as we shall see, I think now that a fourth must be added). I have tried to

- See mainly my book Etice y derechos humenos, Buenos Aires, 1984. 
ground that defence on the connection between each of these principles and procedural and functional features of the social practice of moral discourse, which constitutes the context within which principles like these three (or four) must be necessarily justified.

The first of these principles is the one I called "the principle of the inviolability of the person". This principle proscribes to sacrifice somebody's goods or interests on the sole basis that it contributes to preserve goods or interests of other individuals or of a supposed collective entity. To do that would imply, as Kant said, to use some individuals only as means for ends which are not their own (though there are cases in which we use somebody only as means for our own ends but we do not infringe the principle of the inviolability of the person since we do not frustrate one of his interests).

What this principle prima facie prohibits are interpersonal compensations of benefits and harms, privileges and burdens, goods and deprivations.

The support of this principle of the inviolability of the person is given by a reconstruction of the point of view inherent in moral discourse which takes into account-as authors like Rawls, Nozick and Nagel have pressed- ${ }^{5}$ the basic fact of the separability or independence of people. This is a reconstruction which contemplates the interests of all the people involved in a separate way and does not (as utilitarianism does) treat them as if they were the interests of one and the same individual, and thus, as if the question of whose interests are frustrated and whose are satisfied were irrelevant once it is granted that the net result of comparing the magnitude of the interests at stake is positive. This principle disqualifies holistic conceptions of society which do

See John Rawls, A Theory of Justice, Oxford, 1971, p. 26 and 27. 
not assign intrinsic value to the distribution of benefits and harms among its members, in the same way as we do not care, e.g., about the distribution of pleasures and pains among parts of our bodies.

Once we realize that people are sacrificed or used as mere means not only by positive actions but also by omissions (something that authors like Nozick disregard) ${ }^{6}$, we seem to confront permanently situations in which whatever we do or omit we are sacrificing somebody for the benefit of someone else. This obliges us to seek an interpretation of the principle of the inviolability of the person which rescues it from futility. The interpretation suggested is an egalitarian one: nobody can be sacrificed or deprived of some good without his consent only for the sake of putting another person in a more favourable position (in terms which will be clarified later on) than that of him (with this interpretation a person is not instead, used only as a mere means when he is denied some good or benefit-including that of being free from some burden or sacrifice-which, if enjoyed by him, would put another people in a less favourable position than that of him). From this we can derive a positive duty to increase the autonomy of those who are less autonomous. ${ }^{7}$

This principle serves to establish the function of rights which is to "entrench" some goods or interests of individuals against considerations about the welfare of other individuals or the achievement of some collective goals.

But, although this principle refers to some goods or interests of individuals which should not be sacrificed,

- See an analysis of this in the book cited in the previous note, p.p. 194 et eeq.

7 Idem, chap. IV. 
it does not tell us which are those goods or interests. This is the task of further principles.

One of those principles is the principle of autonomy of the person, which establishes that the free choice and materialization of plans of life or ideals of personal excellence is something valuable and, thus, should be promoted and not interfered with by the state or other individuals.

This principle derives, I think, from the fact that moral discourse is aimed at obtaining consensus, i.e. the free choice of (the same) principles for justifying our actions and attitudes (this is the feature of moral discourse that Kant called "the autonomy of morals", which refers to the idea that moral principles should be accepted in a voluntary and conscious way, and not through coercion, irrational persuasion, etc.). If the achievement of consensus is the immediate aim of moral discourse, genuine and honest participation in it implies the acceptance of a basic norm: that which establishes that the moral autonomy of people - which is given by the free acceptance of principles to guide conduct-is something valuable. But we must distinguish between two kinds of moral principles: those of public or interpersonal morality which prohibit certain actions for their effects on other people, and those of private or personal morality which determine plans of life and define ideals of personal excellence and which proscribe certain actions because of their effect not on other people but on the wellbeing, integrity, moral character, etc. of the very agent of those actions.

Although the basic norm of moral discourse implies that the free choice of interpersonal moral principles is prima facie valuable, it also provides a reason for imposing them in certain cases: the reason being that if some of those principles-like that which prohibits to 
kill another-are not accepted, the autonomy of other people for choosing moral principles will be adversely affected. On the other hand, in the case of the choice of standards of private or personal morality its prima facie value is not counterbalanced by a reason which has to do with the preservation of the autonomy of other people (since they do not take into account the effects of an action on other people). Besides, the imposition of this sort of standards is generally self-frustrating, since the satisfaction of most of them requires a spontaneous conviction. I think that these considerations support the principle of personal autonomy: that which establishes the value of the free choice and materialization of the standards of personal morality and of the plans of life which are determined by them.

From the value of personal autonomy we can derive the value of some goods which are necessary for the choice and materialization of most conceivable ideals of personal virtue and plans of life: those which are constituted by conscious life, physical and psychical integrity, freedom of expression, freedom of movements, freedom of association, freedom of work and industry, the possession and control of some material resources, etc. These goods, which are conferred value by the principle of autonomy, determine the content of basic moral rights, whose function of entrenching the possession of those goods by individuals derives, as we saw, from the principle of the inviolability of the person.

This principle disqualifies perfectionist conceptions of society which imply that ideals of personal goodness may be imposed by the state or other individuals, even by force. These conceptions assume an objectivist outlook of the interests and goods which are the content of rights: unlike the sujectivist vision implicit in the principle of autonomy, the former states that what 
is in the interest of an individual does not depend on his psychological inclinations or preferences. Of course, perfectionism must be distinguished from paternalism, i.e. the policy of inducing or even forcing individuals to satisfy their own subjetive preferences.

Maybe the value of autonomy implies the value of pleasure and the disvalue of pain, but maybe not. In this later case, to be free of pain and to have pleasurable sensations would be, as utilitarianism has emphasized, goods which are not subservient to the value of autonomy. Even when the capacity of an individual to choose and to materialize plans of life were not substancially prejudiced by a certain pain or suffering, it may constitute for him an evil as a pleasurable sensation would constitute a good even though it might not enlarge that capacity. For this reason I think now that we must recognize a further principle which defines the goods that are the content of rights, besides that of autonomy of the person: "the hedonist principle", which assigns value to pleasure and disvalue to pain.

But there is something else yet. I have also defended what I called "the principle of the dignity of the person", which prescribes to take seriously into account the will and consent of individuals in order to ascribe to them normative consequences such as obligations, depravation of rights, responsibilities, etc. This principle rejects a normative variety of determinism which consists in deriving, fallaciously, from the descriptive hypothesis that people's volitions are causally conditioned by different factors the normative conclusion that, consequently, these volitions should not be taken into account as antecedents of normative consequences and should be treated in the same way as involuntary circumstances such as illnesses or the colour of the skin. It is obvious that this normative proposition cannot be inferred from 
the deterministic descriptive hypothesis alone (without violating Hume's principle) and it is far from certain that it can be justified in any other way, since its coherent extension to fields such as those of crimes, contracts, marriage, political representation, etc., would lead us to an unintelligible (and hence, indefensible) model of society. Besides, the opposite to the tenet of normative determinism, i.e. the principle of the dignity of the person, seems to be presupposed in moral discourse, since genuine participation in it implies to take seriously the decision of people to adopt some principles to guide their conduct and to commit themselves to act according to those principles.

From the principle of the dignity of the person, which emerges from the rejection of normative determinism, there derives the possibility of a dinamic operation with rights since it allows us to give up and to transfer voluntary basic rights. Thanks to this principle, it is possible to accept a consensual restriction or self-limitation of the autonomy of people. If the principle of personal autonomy operated alone, it would be possible to constrain people to be autonomous, disregarding their will to relinquish some autonomy. Therefore, this is the principle which justifies such important institutions as contracts and, as I have argued elsewhere, ${ }^{8}$ punishment (whose distribution is grounded on the consent of its recipients).

These four principles constitute a normative system from which a broad set of human rights derives. The principle of personal autonomy and the hedonist principle establish the aggregative value of some goods which are the content of basic rights. But they are limited by the principle of the inviolability of the person which

- See my book Los límites de la responsabilidad penal, Buenos Aires, 1980, cap. III. 
prohibits to deprive somebody of a good in order to put him in a less favourable position (in terms of autonomy of pleasure) than that of others; from this follows a set of negative and positive duties addressed at not deteriorating and, if possible, improving the situation of the less favoured members of society. This principle is in its turn limited by the principle of the dignity of the person which permits other sorts of distributions (i.e. non egalitarian ones) when they are consented to by those who are prejudiced by them.

3. These four principles of a liberal conception of society do not condition their normative consequences to the possession of certain factual properties. They are cathegorical and apply to everybody and everything. But, of course, for enjoying the benefits which ensue from them an entity must have some capacities. This is a mere question of fact: it is not something which emerges from the circumstance that the basic moral principles connect those capacities with some rights: this would imply a "jump" from facts to values or norms which would require to be grounded in further moral principles.

Each of these principles benefits only those entities which have a distinctive capacity. The principle of the autonomy of the person can be enjoyed only by those individuals who can choose and materialize moral principles in general and the ideals of personal goodness and the ensuing plans of life which are the specific referent of that principle. Only for those who have this capacity the states of affairs which are the content of the basic rights are genuine goods. It is not that e.g. a stone has not the right to freedom of movements; this right is just meaningless to the stone since it lacks the capacity for choosing plans of life of which freedom of movements is a prerrequisite. 
The hedonist principle benefits only those individuals who can feel pain and pleasure. It is an empirical fact that this capacity requires the possession of a nervous system, and that its extent depends on the complexity of this system.

The principle of the inviolability of the person is only relevant for those who are self-conscious that they are independent and unreplaceable centres of interests. If somebody had not this kind of self-consciousness but thought of himself as a component of a wider unitary entity, it would be meaningless for him to contemplate his interests in a separate way, as it is absurd to contemplate separately the "interests" of, say, our head by opposition to those of our arm (in deciding, e.g., whether to hurt the latter by means of an injection in order to save the former from some pain).

The principle of the dignity of the person actually applies only to those who are capable of taking decisions and consenting to the consequences of their acts. This capacity is not excluded each time that the will is conditioned by some factor (in that case we would fall in a normative determinism and its unintelligible model of society), but only when it is affected by factors which are unequally distributed in society or that affect only some groups (like minors) which is convenient to exempt from responsibility (of course, things would be different if all the members of society were children).

Each of these capacities admits degrees: for instance, the capacity to choose plans of life may have a greater or lesser extent. Besides, it is obvious that an individual or entity may have one of these capacities but not others. These implies that there are two dimensions in which the degree of moral personality may vary. A full moral person is one who has the four afore-mentioned capacities in their maximum scope. This is, of course, 
an ideal condition; in actual fact, we find individuals or entities which come closer or further to this ideal condition according to which capacities they possess and to what degree. This affects, as it is obvious, the moral treatment of these individuals or entities: Think, for instance, in the case of some inferior animals and suppose that the only capacity they possess, of all those mentioned earlier, is the capacity of having pleasurable and painful sensations, while they lack the capacities to choose plans of life, to be self-conscious as independent centres of interests and to consent to the normative consequences of their acts. In this case, it would be morally bad to cause painful sensations to these creatures or to prevent them from having pleasurable sensations, but it would be possible to compensate the greater pleasure of some with the lesser pains of others, they would not be entitled to those goods which are means for the choice and materialization of plans of life, and their acts would not be taken as antecedents of normative consequences so as to imply consent to them. There are possible intermediate situations of superior non-human animals which add to the capacity of having painful or pleasurable sensations that of being conscious of their independence with regard to other centres of interests; in this case, the afore-mentioned compensations are not acceptable, though the treatment is similar in all other respects.

I have been talking of "capacities" as the conditions which allow individuals or entities to enjoy the benefits of the four liberal principles. But this seems wrong since only an actualized capacity allows that enjoyment; it might be said, thus, that what is required for enjoying the rights is the actual exercize of the capacities. This is true, but, nevertheless, we must resort to the notion of capacity: this is so because the idea of rights 
is important for planning courses of actions, and for that planning we need to know who can enjoy the benefits ensuing from moral principles, and these comprise individuals who do not enjoy now those benefits but would enjoy them at the time of the result of the action if some impeding conditions disappeared at that time, perharps as result of our very action.

Once we focus on the concept of capacity the main problem is to identify a set of circumstances or facts which (i) prevent the actualization of that capacity and (ii) are compatible with the ascription of it to the agent. Somebody might say that the only relevant fact satisfying those requirements is the will of the person, and so that we can solely admit as moral persons those individuals who have non-actualized capacities only because they do not want to exert them. But if the only kind of admissible fact were the will of the individual, not only would there be many cases in which this condition would not be applicable because of the sort of entity under consideration or the sort of ability we would speaking of (like that of self-consciousness), so that in those cases a non-realized capacity would not be possible, but we would also reach some absurd conclusions: for instance, the conclusion that an individual lacks the distinguishing capabilities while he is asleep.

Some others, in view of the former considerations, might argue that any kind of fact may be taken as preventing the exercize of a capacity with which it is compatible. But this would lead us to other ridiculous conclusions, like, for instance, that a stone is a moral person, since it has the relevant capacities which are not actualized simply because of the lack of a developed nervous system.

I think that, since we resort in this context, as I said, to the concept of capacity in order to plan actions whose 
future effects will satisfy our basic moral principles, the circumstances which we must take as preventing the actualization of a capacity we ascribe to an individual must be those that can be overcome by the normal course of events or by available technical means. We can only care for those entities which will probably enjoy in the future a good which we may provide now to them, either because they will come naturally to acquire the conditions for that enjoyment or because they would acquire them if we do something which is within our reach.

Is the existence of the entity one of those circumstances which prevents the actualization of a capacity that we ascribe to an individual? Some normal courses of events end up in the existence of entities and in many cases (like that of human beings) it is technically possible for us to contribute to it. However, there is an obvious reason for denying that the existence of an entity is one of the circumstances which prevent the actualization of a certain capacity: it does not satisfy the above mentioned requirement (ii) since a non existent entity cannot be capable of anything (it is not merely that it has a non-realized capacity). Hence, non-existing entities are not moral persons.

For ascribing moral personality it is not only relevant the question of the existence of the respective entity but also the question of its identity through time and space. Since the principle of inviolability of the person prohibits to deprive a person of some good in order to put another person in a more favourable position than that of him, it is highly relevant to determine whether the objects of a deprivation and of a benefits are the same or different persons.

As it is well-known, there are different conceptions 
of personal identity. Dereck Parfit ${ }^{9}$ distinguishes two conceptions resorting to the criterion used earlier in relation to the concept of man: according to him, there is a "simple" view of personal identity which makes it dependant on some primitive fact and confers to it an "all-or-nothing" character, and there is also a "complex" view which relies on a plurality of facts (a concatenation of biological and psychological processes) which may be given in different degrees; this last view allows us to say that personal identity may diminish and vanish even within the same biological life in so far as the concatenation of memories, attitudes, evaluations, etc., becomes progressively weaker.

This has deep ethical implications, though I do not share all of Parfit's conclusions about them. ${ }^{10}$ The possible adoption of a complex view of personal identity would imply that one cannot be obliged to assume consequences which would be enforced in a distant future, since this would imply to bind another person. From this conclusion a justification of the statute of limitation may be inferred. Similarly, we might prevent, without incurring in a perfectionist stand, that a person causes what is apparently a harm to himself, since when the harm is sufficiently delayed in time its victim could be in fact (at least partially) another person. The problem of whether the autonomy of somebody can be limited when he adversely affects what seems to be his future autonomy, is similar, as I have said elsewhere, to the paradox of the sovereignity of Parliament which has been analyzed by authors like Hart: ${ }^{11}$ if it is accepted that among the sovereign powers of Parliament there is

\footnotetext{
- See Reason and Persone, Oxford, 1985.

10 See B́tica y derechos hxmanos.

11 See The Concept of Law.
} 
the faculty of restraining its own sovereignty for the future, then Parliament may cease to be sovereign. On the other hand, denying this faculty to Parliament seems to be contradictory with the atribution of full sovereignty. But both in the case of Parliaments' sovereignty and in the case of personal autonomy, the problem is seen in a different light if we adopt a complex view of the identity of the institution or person in question and we accept that there might be a lack or attenuation of the identity between the individual or entity who undertakes the decision to limit the autonomy or sovereignty and the individual or entity who suffers that limitation. If we see these cases from the perspective of the complex view of identity, the supposedly logical paradox of whether autonomy or sovereignty includes or not the faculty of self-destruction vanishes and is replaced by the ordinary normative problem of distributing power between different people or institutions.

4. These general considerations about a revised concept of moral person have deep implications for vexed questions related to the right of different classes of individuals or entities. Though a full articulation of those implications would require a much longer and throughout treatment, let us give, in this final section, a quick and tentative look at those implications, as a sort of prologue to such a treatment.

(i) Non-human animals. We have already seen that the treatment of non-human animals may vary according to the capacities they possess. Of course, many species of animals have the capacity of feeling pleasure and pain, though the extent of this capacity varies greatly. On the other hand, it is extremely doubtful that any species of non-human animals has the capacity to choose plans of life (even of the shortest scope) and it is almost certain that none has the capacity to consent 
and to take decisions. It is crucial to determine whether there is some non-human animals who have the capacity to see themselves as separate centres of interests (I do not know whether or not this is true of certain species of non-human animals).

If we are in front of animals which are not capable of being conscious of their own separate identity, the principle of inviolability of the person is not, as I have said, applicable, and, hence, we can admit interpersonal compensations of benefits and sacrifices. This means that we can impose an animal a pain or sacrifice in order to produce to other animals of the same or other species a greater pleasure or benefit. The probability that most of the candidates to be benefited with the sacrifice of this animals are men confronts us with the difficult problem of comparing degrees of pleasure and pain with degrees of expansion and contraction of the autonomy of people. When the non-human animals are self-conscious of their separateness, we cannot sacrifice one of them only for the reason that this benefits to a greater extent another animal, human or not. But there are situations in which whatever we do or omit we infringe the principle of inviolability of the person, because we are sacrificing someone in order to benefit another; in this case, the said principle is not, once again, applicable, and it gives place to the aggregative application of the hedonist principle and the principle of autonomy (this allows us to kill, e.g. a dog even supposing that it is self-conscious of its own identity-in order to save the life of a man).

(ii) Foetuses. A foetus seems to be a moral person in the sense explained. Though it is not self-conscious of its own identity, does not choose plans of life, does not adopt decisions and has probably a low response to pleasure and pain, it is, by and large, the same individ- 
ual as that who will acquire these attributes with the normal course of things, or, perhaps, with the help of available technical means (this is not, instead, the case of a spermatozoon). We do not use to say that a foetus (like a child) has a non-actualized capacity of doing the above-mentioned things (we say, at most, that it has a potential capacity). But this seems to be a mere accident of language, since according to what we saw earlier, there is solely a difference of degree between the relevant circumstances of a foetus and of e.g. a man who is temporarily unconscious (besides, a potencial capacity is a potential potentiality, that is a capacity of low degree).

This means that the foetuses have moral value and, thus, that it is disvaluable to destroy or hurt them. As they are potentially self-conscious of their separateness as centres of interests, they cannot be sacrificed for the sake of benefiting other beings. But, to the effect of the aggregative application of the principle of autonomy and of the hedonist principle, in those situations in which the principle of the inviolability of the person is not applicable (because we infringe it whatever we do or omit), it is important to determine whether the foetus has the same value as a born individual. I think, very tentatively, that it is possible to defend the thesis that the foetus has less value than, say, its mother, on the ground that its "capacities" to choose plans of life and pain are lesser than that of the latter. This seems to be so, first, because more conditions need to be given for the capacities of the foetus to be actualized (with the consequence that that actualization is more uncertain) and, secondly, because the identity connection between the foetus and the person it will be when its capacities are actualized is looser than the one which is given between a stage in the life of a born man in which those 
capacities are not actualized and a stage in which they are. Since the value of an individual at any stage of his life in which his capacities are not actualized is solely a reflex of the value he has at the stage in which they are actualized, the former value will be lesser in so far as that stage is further away from the latter. This possible conclusion might justify our common conviction that a foetus may be killed in order to preserve the life or the physical integrity of the mother.

The previous considerations bear, of course, consequences about the treatment of abortion. However, I think that here we tend to confound three very different questions. The first is whether the death of the foetus is something evil or disvaluable. The second is who-and under what conditions - is obliged to preserve the foetus or not to cause its death. And the third is whether it is morally legitimate to impose coercively-for instance, through law-that supposed moral obligation. A positive answer to each of these questions does not imply a positive answer to the following one; the opposite is true in the case of a negative answer. For instance, if we conclude, as I think we should, that the death of a foetus is something which is morally evil because it implies the loss of the potential personal autonomy and of a source of pleasurable sensations, from this does not yet follow that somebody-specially the mother-has the moral duty not to cause that death. The duty in question must be specially justified in view of the severe restriction to her autonomy that pregnancy and upbringing represent (a possible principle which might ground that duty takes into account her consent which may be given by voluntarily incurring in sexual intercourse with foresight of the consequences and the possibility of avoiding them). But even when the moral duty to prevent or not to cause the death of the foetus were established, from 
this it would not follow necessarily that the legal punishment for the violation of that duty is morally justified. Though from the principle of autonomy derives a prima facie reason in favour of the imposition, even by force, of duties directed at preserving the autonomy of other individuals, that reason can be overriden by others (like the consideration that, by so doing, we compel women to seek abortion in clandestine and, consequently, dangerous conditions).

(iii) Disabled people. People with mental or physical handicaps, have, of course, different degrees of diminution of some of the above-mentioned capacities. This may reach a point-e.g. the case of irreversible and massive brain damage - in which those capacities are excluded because neither the normal course of events nor the use of available technical means will bring about what might be considered an actualization of them. In particular relation to the capacity to choose and to materialize plans of life it is necessary to make two comments: First, not always the diminution of the capacity to choose plans of life is accompanied by a diminution of the capacity to materialize the plan of life actually chosen within the narrow limits imposed by the handicap; it is obvious that many disabled people achieve a high degree of realization of the project they have adopted, frequently with great strenght of will. Secondly, the choice of a plan of life is a consequence of the choice of an ideal of personal goodness (which is what really constitute the autonomy of people) and the capacity for this latter choice is not diminished in the case of physical handicaps. Therefore, the capacity required for enjoying the principle of autonomy of the person is not substantially limited in cases like blindness or paralysis.

How do handicaps, therefore, affect the application of the four liberal principles? The first thing to take 
into account is that, if we recognize that moral rights are not only violated by positive actions but also by the omission to provide people with the means which would give them an equal opportunity of choosing and materializing plans of life, we have the duty to provide disabled people with the resources which may help them to overcome their defficiency-or compensate them for it-in so far as it is technically possible and does not diminish the autonomy of the less autonomous people.

When it is impossible to overcome or to compensate the handicap, it is obvious that the individual will not be able to enjoy the benefits which derive from one or various of the four principles. An oligofrenic, for instance; has a quite restricted capacity for choosing and materializing plans of life and a completely paralyzed man has few opportunities for feeling pleasure. This makes that, for these people, many of the resources which are means for the development of autonomy, the achievement of pleasure or the prevention of pain are not genuine goods. In that case, to provide these resources to them will be superfluous and will constitute a waste that will violate the rights of those who may be benefited with them (since there are surely duties towards the less autonomous which are not satisfied because of the lack of resources). If there are some goods that the individual may enjoy, he cannot be deprived of them for the sake of benefiting other people unless he also lacks the capacity of consciousness of his individuality (in which case we may compensate his deprivation with the greater benefit to others). All this implies, as it is obvious, that the vegetative life of someone affected by irreversible massive brain damage has not intrinsic value, though it may have instrumental value for other people, like his relatives.

(iv) Collective entities. The recognition of rights of 
supraindividual wholes (like nations and associations), as something different from the rights of its members, depends of course on the ontological admissibility of those wholes. There are, as it is well-known, serious objections to that admissibility, which lead to the current outlook of collective entities as logical constructs which are alluded to in propositions which are equivalent to propositions about the behaviour of people in relation to certain rules and other social circumstances. But there are specific ethical arguments against the recognition of rights of collective entities: It is not plausible to conceive them as irreductible moral person if we assume a subjectivistic view of interest. All the attributes of moral personality which I have mentioned require some sort of psychic activity with a certain degree of development, and, in particular, the capability of self-consciousness as an independent centre of interests requires to have an autonomous mind. The scientific knowledge available to us seems to indicate that those requirements are only satisfied if the entity in question possesses a nervous system, and some of them in particular depend on a nervous system with a high degree of development. Therefore, although it is, of course, legitimate to speak of the rights and duties of a state, an association or any corporation of persons, they are not irreductible moral rights and duties, but to refer to them is a convenient and simplified way of alluding to a set of rights and duties of individuals.

(v) Past and future persons. As I said before the nonexistence of an entity or an individual excludes its or his capacity. Hence, a dead man or a member of future generations is not a present person.

This conclusion must not be confused with a quite different one; that a moral person can only be harmed while he subsists. I think that this presupposition is 
false: the autonomy of a person may be adversely affected before or after the lapse on which he exists. For instance, the destruction of the only concert-hall in town may spoil the musical vocation of a person who was not born at the time of the event, and the same destruction may frustrate the project of the deceased millonaire who has bequeathed the hall with the intention of making a permanent contribution to the community. It seems to me that sometimes this thesis is rejected because of the wrong assumption that it derives from an objectivist (and, hence, perfectionist) conception of interests of individuals, according to which they do not depend on their subjective preferences. But this is not so: the fact that an interest originates in the subjective attitudes of an individual does not mean that for it to be satisfied or frustrated the corresponding psyche must subsist; the same seems to be the case of beliefs; we say, for instance, that some facts which occur today show the falsity of beliefs which somebody held in a distant past.

However, there is an obscure problem, with which I cannot deal here, concerning the applicability of the principle of inviolability of the person. A future person has not definite identity; moreover, most of our acts which may harm his autonomy may altere his identity. ${ }^{12}$ Hence, it is problematic to say that we are sacrificing him in order to benefit other people. If these doubts were confirmed, we would have to treat future persons in the same way as those beings to which the aggregative but not the distributive principles are applicable. But this requires much more ellaboration in the context of another article.

See this point in Parfit, op. cit. 


\section{RESUMEN}

El propósito de este trabajo es analizar el concepto de persona moral como portadora de derechos morales búsicos. Se trata de explorar la conexión entre este concepto y la clase de los seres humanos. Muchas personas aceptan que existe una relación intima entre el hecho de ser hombre (i.e. ser humano) y la propiedad de ser portador de un derecho.

Bajo este punto de vista, parece que la única condición para gozar de un derecho moral es ser humano. Esta condición cumple con una aspiración igualitaria, ya que afirma que todos los hombres deben tener cualquier derecho en el mismo grado. La condición cumple con la proposición: todos los hombres son iguales.

Si esta proposición se interpreta como descriptiva, es falsa. $\mathrm{Si}$ se interpreta normativamente, no es plausible, ya que todos los teóricos de la igualdad aceptan el hecho de que no todos los hombres deben de ser tratados como iguales. La proposición podrfa tener sentido si la interpretamos como una proposición analítica, es decir, si afirmamos que el predicado 'hombre' tiene caracter de todo o nada, lo que significa que todos los hombres son igualmente hombres.

Estas reflexiones nos llevan a la necesidad de analizar el predicado 'hombre'.

Una primera definición podría darse en relación a ciertas propiedades biológicas; otra, de acuerdo con ciertes características tales como la racionalidad, la inteligencia o la capacidad de decidir y de elegir valores. La propiedad biológica no admite grados, por esto puede decirse que tiene un carácter de todo o nada.

El concepto de hombre definido en términos biológicos puede servir para propósitos té́ricos y prácticos; sin embargo no nos sirve para adscribirle al hombre ciertos derechos morales b́sicos.

La otra definición tiene consecuencias no deseadas, ya que les características en cuestión no son de todo o nada. Los hombres, según esta tesis, serían merecedores de los derechos de acuerdo con el grado de racionalidad, inteligencia, capacidad de elección 
de valores, etc. Esta consecuencia serf́a elitista. Por esta razón la proposición 'todos los hombre son iguales' parece analíticamente falsa.

Tenemos que rechazar la presuposición de que el concepto de persona moral denota una clase de individuos a los que distinguen ciertas propiedades fácticas mencionadas en principios morales fundamentales y que son condición para tener ciertos derechos.

Necesitamos un cambio radical en la estrategia de la caracterización de la personalidad moral. Necesitamos, primero, establecer los principios básicos y categóricos de los que se deriven los derechos morales; a saber:

1) El principio de la inviolabilidad de la persona.

2) El principio de la autonomía de la persona.

3) El principio hedonista.

4) El principio de la dignidad de la persona.

El principio de la autonomía de la persona y el hedonista, establecen el valor agregado de ciertos bienes que son el contenido de los derechos búsicos.

Ahora bien, éstos están limitados por el principio de la inviolabilidad de la persona que prohibe privar a alguien de un bien, si con ello se le deja en una situación peor que la de las otras personas. Este principio, a su vez, está limitado por el principio de la dignidad de las personas, el cual habla de ciertos tipos de distribución.

Cada uno de estos principios beneficia a aquellas entidades que tienen una característica distintiva.

El de la autonomía de la persona sólo puede ser disfrutado por los individuos que eligen y materialis an los principios morales en general. El hedonista sólo beneficia a los individuos que pueden sentir placer y dolor. El principio de invioliabilidad de las personas sólo se aplica a las que son autoconscientes, independientes y centros de interés. El de la dignidad beneficia a las personas que son capaces de tomar decisiones y de aceptar las concecuencias de sus acciones.

Para gozar de los derechos, derivados de los principios, se necesi- 
tan ciertas capacidades que son graduales y que son las condiciones que permiten a los individuos y a las entidades gozar de los beneficios de los principios liberales.

Como únicamente la capacidad actualizada permite el goce, es necesario examinar dicha noción. Este examen nos remite a la noción de 'entidades existentes' que son susceptibles de tener personalidad moral.

Para adscribir personalidad moral a una entidad o a un individuo, son relevantes las cuestiones de la existencia y de la identidad a través del espacio y el tiempo. Esta cuestión esta íntimamente relacionada con la de la identidad personal. Dado que el tratamiento de este tema sería demasiado largo, es mejor mencionar algunas de sus implicaciones, a manera de prólogo. Dichas implicaciones se refieren a cuestiones relacionadas con distintas clases de individuos o entidades, como son: los animales no humanos, los fetos, las personas minusválidas, las entidades colectivas y las personas pasedas y futuras. 